Original Research Paper

\title{
The Informal Funds Transfer System "Hawala" as a Segment of the Shadow Economy: Social Impact Assessment and Framework for Combating
}

\author{
Bakhyt Moldatjaevich Nurgaliyev, Kanat Sametovich Lakbayev, \\ Alexey Vladimirovich Boretsky and Aiman Kudaibergenovna Kussainova
}

Karaganda "Bolashak" University, 100012, Erubaev St., 16 Karaganda, Kazakhstan

\author{
Article history \\ Received: 22-10-2015 \\ Revised: $12-11-2015$ \\ Accepted: 17-11-2015 \\ Corresponding Author: \\ Bakhyt Moldatjaevich \\ Nurgaliyev \\ Karaganda "Bolashak" \\ University, Karaganda, \\ Kazakhstan \\ Email: nbake@mail.ru
}

\begin{abstract}
The research considers the problems of social impact assessment in the informal funds transfer systems based on the principles of the "hawala". The international experience, leads us to express an opinion that the degree of its public danger through the possibility of financing terrorism, extremism, drug trafficking and transnational organized crime is underestimated. The methods of counteracting these processes by the state and society are suggested.
\end{abstract}

Keywords: Informal Funds Transfer Systems, Shadow Economy, "Hawala", Financing of Terrorism and Extremism

\section{Introduction}

The dynamic development of human civilization and the processes of globalization are accompanied by new threats to global security, such as international terrorism, transnational drug trafficking, illegal migration, which require development of new approaches to control them. It is obvious that effective counteraction to such threats is effective control over the economic basis of the illegal activities in these areas. But, while control over the legal financial flows is carried out in many countries, the informal systems which are able to pass through no less amounts, are still poorly controlled by the relevant government agencies and international organizations.

Similarly, the informal funds transfer systems being an integral part of the shadow economy are hardly researched in Kazakhstan, although the extent of their impact on this area, judging by the experience of foreign (especially developing) countries can be quite significant, if not decisive.

De Soto (1990) an economist from Peru, had done a quite detailed research on this issue almost thirty years ago and has found that the developing economies are largely inherent in the "shadow" segment, which occupies leading position in some industries. For example, the shadow economy "zone" in Peru comprised almost half of the economically active population, more than $60 \%$ of the working hours and almost $40 \%$ of official gross domestic product. More than $90 \%$ of the transport park was illegal in Lima, capital of Peru (De Soto, 1990).
Naturally, the shadow economy at such impressive scale ought to have their informal funds transfer system. One of them is the "hawala" that has been mentioned more often in recent years in connection with the financing of international terrorism.

\section{Materials and Methods}

Among the main research methods there were used dialectical, analysis and synthesis, logical and comparative legal methods which provide an adequate assessment of possible significant effect on the shadow and legal economy of Kazakhstan and informal funds transfer systems based on the principles of the "hawala".

With the help of these methods, based on the study of factual material and literary sources there was given an analysis of consequences for society and the state and suggested practical measures to counter this social phenomenon that becomes more and more criminal in nature.

\section{Main Part}

It began after the notorious terrorist attacks in the United States on September 11, 2001. A few weeks after that, the US intelligence agencies have blocked the accounts of Al-Barakaat, a large financial institution from Somalia, which had a retail network in North American, used by Somalis to send money to their families, by analogy with the American Express. Al-Barakaat was part 
of the "hawala" system and through it the money of "AlQaeda" has been transferred (Robinson, 2003). In addition, the anti-Israel groups "Hamas" and "Hezbollah" use the same methods and the same facilities for the remittance (Greenberg et al., 2002). Similar processes occur in the immediate vicinity of Kazakhstan borders. For instance, two members of the East Turkestan Islamic Movement (ETIM), were arrested in Dubai in July 2010 on suspicion of preparing a terrorist act against a Chinese shopping center. The detainees admitted that they have been trained in the "al-Qaeda" camps in Pakistan's Waziristan and the funds in the amount of $\$ 10,000$ for the terrorist attack organization had been received through the "hawala" network from Turkey (Pantucci, 2010; Russian Encyclopedia "Tradition", 2012).

Such popularity of the "hawala" lately is due to tightening control over the banking activities in most countries of the world. Therefore, criminal and terrorist groups use the export-import offices, exchange offices, auctions and charity organizations, which are not controlled by the state.

However, the phenomenon of the "hawala" is not so unequivocal and has a fairly solid history.

The "hawala" is a general, most commonly used name of the existing informal network of the international system of remittance between individuals and organizations (UD, 2007). These systems are based on the close business and family ties, which are established on mutual trust-the word "hawala" has its roots in the Arabic language where it means "exchange" and "cash receipt", "bill", also it acquired the value of "trust" in Hindi.

It was formed in the Indian subcontinent long before the Western banking system appeared in the Muslim East. In the early middle ages, when development of trade relations necessitated the emergence of cash payments, the "hawala" was designed to protect merchants from robbery on transport routes, primarily on the Great Silk Road (Khokhlov, 2007). Another reason for its occurrence was political turmoil and deep distrust of banks. The Chinese named it fei ch'ien ("flying money"), in other parts of the world it is known as "chop" or "hundi", in the Philippines-"padala", in Pakistan-"hudzh", in Hong Kong-"hui kuan", in Somalia-"ksa-vilaad", in Thailand-"phei kwan" (Shvarev, 2005) (and almost always it is based on family or tribal ties) (Benitsky et al., 2008).

Such illegal banking systems operate on the principle of conventional banks, but do without any written confirmation of financial transaction. Also, a real money transfer is not required. The money is issued to another person in another country in another currency. This amount is taken from the reserves of the partner bank that works on the same system. Everything here is based on personal trust and the relative ease of operation-the sender of money puts them on account of illegal bank. A proof that money has been transferred is any seemingly nondescript subject-a postcard or playing card torn in half. One half of the card or postcard is in hands of the sender and the other is presented in the country where the money is due to be received. In this way, there is no need to move cash from one country to another. Hence, one of the main features of such systems is the complete anonymity of the sender and the recipient; high speed and low cost of transfers, in comparison with current international payment systems.

Compared with the traditional means of remittance, the "hawala" system seems cumbersome and risky, but there are some reasons for the preference of this system today, including:

- High costs of banking services through official channels

- Unavailability of easily accessible official financial institutions in remote areas of certain countries (Afghanistan, Yemen, Somalia)

- Lack of confidence in conventional banks

- Delays in the official sector, due to holidays, weekends and time differences

- Absence of an efficient banking infrastructure so that local banks do not have the means to send money abroad

- $\quad$ Rigid (strict) exchange control regulations

- To avoid currency reporting

- Wide discrepancy between the official and black market exchange rate

- Cultural, political and social causes

- Illiteracy of population

- For criminal purposes, such as money laundering, terrorist financing, tax evasion, adopted the "hawala" network (Pohoata and Caunic, 2007)

Thus, the remittance market in Kazakhstan in 2014 was represented by 21 Money Transfer Systems (MTS), although even the fierce competition in direction of the CIS countries has not led to a significant reduction in the average cost to a very low level. The fees for remittance (bank commission) to the Russian Federation and other CIS countries range from 4.5 to $1.5 \%$ for US $\$ 100$, in the direction Germany-Turkey banks charge more than $6 \%$, while in the direction Malaysia-Indonesia, where the commission is one of the lowest, the fee is about $1.5 \%$ (Fig. 1 and Table 1).

The hawaladars offer excellent conditions to its customers by developing highly effective means to transfer money to any distance, successfully competing with powerful financial systems such as Western Union and Travelex. Using this system, the customers can deposit cash in any country and currency, expecting the same amount in local currency of another country, including remote rural areas, within $48 \mathrm{~h}$ (Ballard, 2006). 


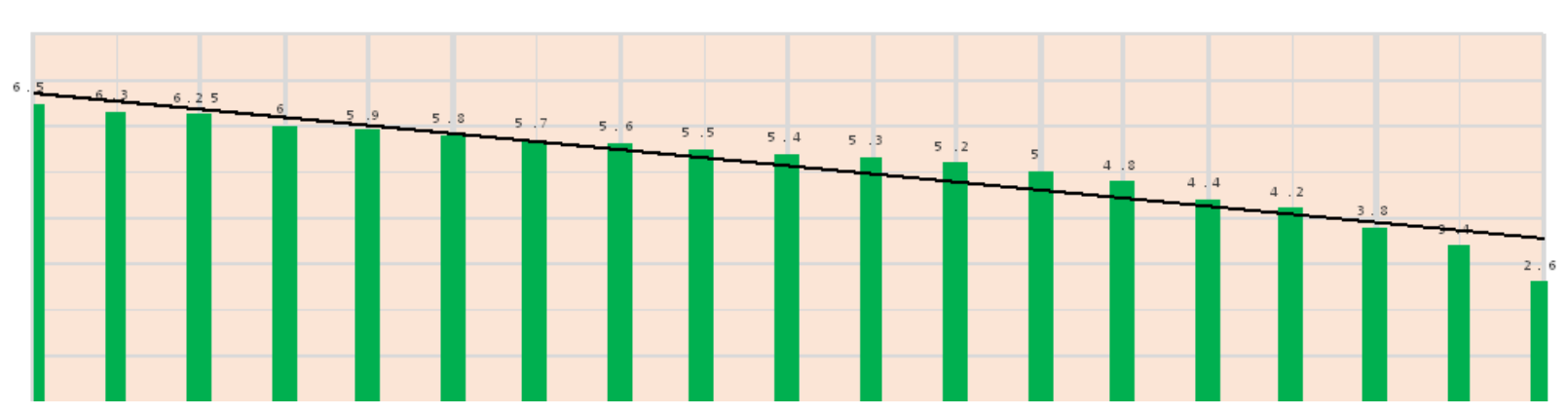

Fig. 1. The average amount of bank commission for the transfer US \$200 (\%) to popular destinations

Table. 1. Transfer fee for US \$200 and US \$1,000 (Source: Database of the World Bank on remittances)

\begin{tabular}{|c|c|c|c|c|}
\hline \multirow[b]{2}{*}{ Companies } & \multicolumn{2}{|c|}{ From Kazakhstan to CIS countries } & \multicolumn{2}{|c|}{ From Kazakhstan to other countries } \\
\hline & US $\$ 200$ & US $\$ 1,000$ & US $\$ 200$ & US $\$ 1,000$ \\
\hline Western union & $4,5 \%$ & $3,7 \%$ & $11 \%$ & $5 \%$ \\
\hline Faster & $2 \%$ & $2 \%$ & no information & no information \\
\hline Fast mail & $2,5 \%$ & $2 \%$ & no information & no information \\
\hline Golden crown & $1,5-3 \%$ & $1,5-3 \%$ & no information & no information \\
\hline Contact & $2 \%$ & $2 \%$ & $3 \%$ & $3 \%$ \\
\hline Unistream & $2 \%$ & $1,8 \%$ & $3,8 \%$ & $3,8 \%$ \\
\hline Anelik & $1,5 \%$ (rouble) & $1,5 \%$ (rouble) & $3 \%($ dollar, euro $)$ & $3 \%$ (dollar, euro) \\
\hline Leader & $1,5 \%$ & $1,5 \%$ & no information & no information \\
\hline Money gram & $1,5 \%$ & $1,6 \%$ & $10 \%$ & $5 \%$ \\
\hline Coinstar money & $3 \%$ & $3 \%$ & $3 \%$ & $3 \%$ \\
\hline Blizko & $2 \%$ & $2 \%$ & no information & no information \\
\hline
\end{tabular}

Table. 2. The average amount of commission for sending US \$ 200 to various destinations (\%) (Source: Database of the World Bank on remittances)

\begin{tabular}{ll}
\hline Netherlands & 6,5 \\
Serbia & 6,3 \\
Nigeria & 6,25 \\
Canada, Jamaica & 6,0 \\
Great Britain & 5,9 \\
USA, China & 5.8 \\
France, Algeria & 5,7 \\
Senegal & 5,6 \\
Mexico & 5,5 \\
Honduras & 5,4 \\
Philippines & 5,3 \\
Morocco & 5,2 \\
Guatemala & 5,0 \\
Italy, Albania & 4,8 \\
India & 4,4 \\
Haiti & 4,2 \\
Saudi Arabia & 3,8 \\
Pakistan & 3,4 \\
Bangladesh & 2,6 \\
\hline
\end{tabular}

The attractiveness of the "hawala" is caused by economic and cultural factors. This system is less expensive, faster, more reliable and more convenient compared to the official financial sector (Table 2).

The speed of transfer is incomparable as wellremittances through SWIFT and other similar systems can take 2-3 days and more. These peculiarities deter customers and raise great interest in such systems as the "hawala" in international organized crime groups-the document states (UD, 2007).

A few publications show the existence of the informal remittances system "hawala" in Kazakhstan, used among businessmen mostly to transfer funds involved in informal trading activities. Thus, Todoroki et al. (2011) who had investigated the banking industry in Kazakhstan, wrote that the "hawala" system, apparently, works between Kazakhstan and trading partners such as China, Turkey, the United Arab Emirates and Uzbekistan. According to the information acquired from the market participants' interviews, the real volume of imports from these countries is much higher than official data. The existence of informal trade spurs the need for informal payment channels for imported goods, as it is impossible through official channels in Kazakhstan. The informal remittances system "hawala" operates in Kazakhstan, albeit in a strictly controlled environment. In the official crime statistics in Kazakhstan, there is no indication that such remittances system as the "hawala" is regularly used by criminals. Apparently, it allows for settlements in the informal trading activities. Entrepreneurs involved in it, use its services due to the absence of necessary documents for use of official remittance channels (Todoroki et al., 2011). 


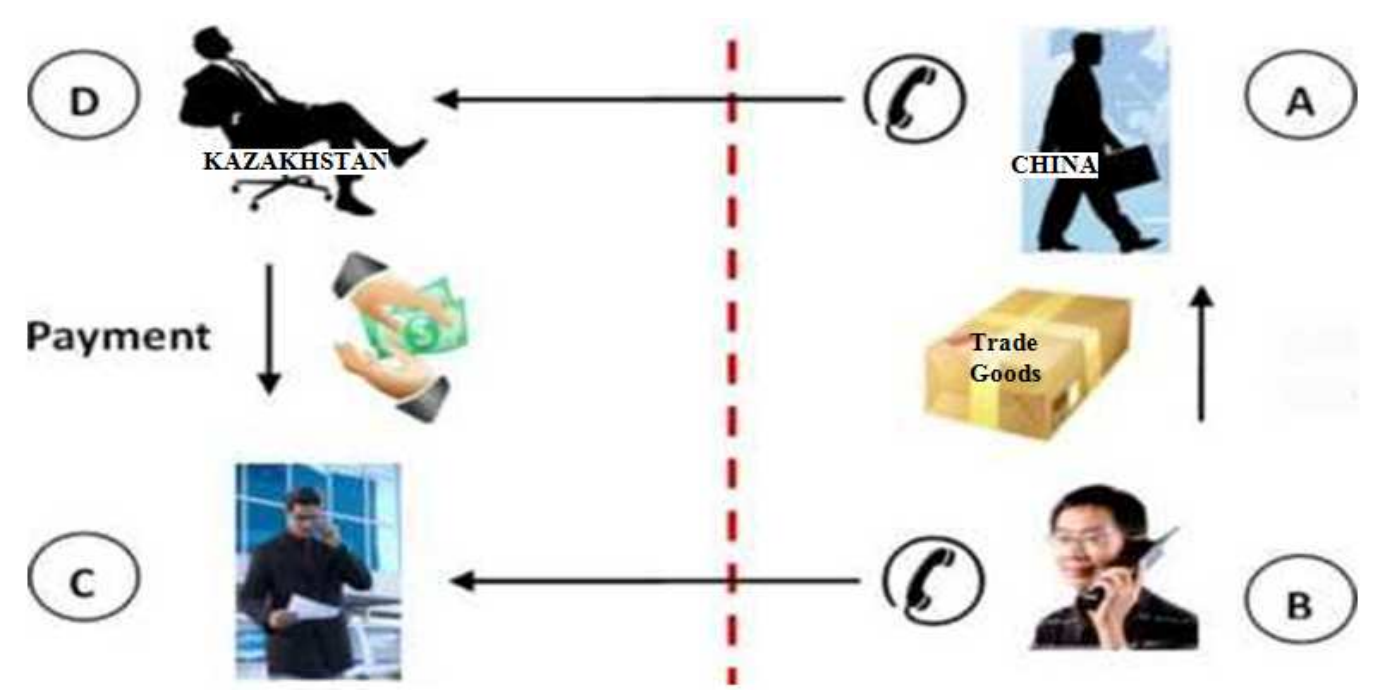

Fig. 2. Simplified diagram of common charges used in informal trade by the "hawala"

A Fig. 2 illustrating the mechanism of money transfer between China and Kazakhstan is below.

A citizen of Kazakhstan (A) plans to go to China for the purchase of goods for sale and he needs the money to pay for the goods. The seller in China (B) has his representative in Kazakhstan (C). Chinese seller in China (B) recommends (A) that the payment should be transferred to $(C)$. Then (A) calls a friend or relative (D) in Kazakhstan and asks him/her to pay the money to (C). (C) receives the money in Kazakhstan and (B) gives the goods to (A) in China. (B) and/or (C) may use the bank accounts for payments. In this scheme, the Chinese entrepreneur acts as an informal payment service that helps Kazakh businessman buy the goods without any official documentation.

The following basic features are inherent to operations similar to the "hawala" in Kazakhstan:

- They are most often used for payment for the informally imported goods

- The new clients are accepted only upon recommendation from acquaintances

- The commission is charged at a rate of about $1 \%$, which is less than the official funds transfer cost, especially in the direction of non-CIS countries

- The clients of the systems do not work with small amounts (say, less than US \$10,000)

A team of researchers was able to talk with several business people who use these systems themselves, or know someone who uses these services. However, fearing the possibility of legal consequences, the source persons, would not provide any names, contact information and the location of these service providers. It is obvious that these channels are very vulnerable to money laundering and terrorist financing, since criminals can take advantage of these underground informal transfer systems (Todoroki et al., 2011).

There are several reasons for the development and such high popularity of the "hawala". First of them is the growth of labor migration worldwide. According to official data, more than 200 million people, or $3 \%$ of the world's population have been living outside of their historical homeland in 2006. Naturally, there was an acute demand for an effective and cheap system of remittances to their homeland. In addition, fees charged by the "hawaladars" are one-two digits lower (1-2\%) than in money transfers through Western Union or other similar legal framework of the banking system. The transfer costs of large sums are even cheaper-tenths of a percent. Because of this, for example, the turnover of the "hawala" in India estimates up to $40 \%$ of GDP (it was \$ 3.6 trillion in 2005) (Khokhlov, 2007).

It seems impossible to make an accurate assessment of its volumes on a global scale, but it comes to trillions of dollars a year (Faith, 2011).

Funds transferred through the hawala do not circulate in the currency market of the country they are sent. The hawala transfers leave rare or intricate paper trail, if any even when using the texture manipulations, a mixture of legitimate goods and illegal money, confusion "real" price and possibly complex international delivery network to establish the trail is much more complex than a simple bank transfer.

Research money laundering Hawala found that even the "core" hawala transfers can be difficult to track and link to the original, the criminal source of money (Samarasinghe, 2006).

Among the competitive advantages of the "hawala" also include: 
- The sender does not need to submit any documents, which is advantageous to the illegal migrants and saves their time (Maimbo, 2003). The minimal documentation and accounting requirements will help reduce the time required for transmission operations. This informal method of transmitting functions, leaving no paper trail; no contracts, bank records or operations and still those who use the "hawala" network can handle thousands of dollars around the world in a few hours. In addition, proof of payment is instantaneous and the entire transaction can be completed within a few minutes (Maimbo, 2003)

- After the transaction is completed, there is no need for accounting and reporting for either no regulatory requirements for customer identification. The "hawala" transactions leave no paper trail, business documents or financial records for law enforcement agencies to track the origin of the transfer (Chene, 2008)

- Availability of the network even in the most remote areas of some countries (Afghanistan, Yemen, Somalia) that allows you to transfer money without time delay due to holidays, weekends and time differences

- Even today, despite the existence of 17 banks, including branches in rural areas of Afghanistan, about $90 \%$ of the population uses the "hawala" network. During the period of the "Taliban" movement control over Afghanistan, the figure was $100 \%$ (Katzman, 2011)

- The functioning of the "hawala" is not susceptible to wars, civil unrest, ethnic conflicts, economic crises, weak banking institutions, as well as to economic sanctions and blockade (Katzman, 2011)

The special qualities of the "hawala" network, allowing it to play a significant role in various conflict situations, are now constantly reported by experts of the International Monetary Fund and the World Bank. The transactions carried out within the "hawala" system are "highly adaptable to the conditions of war, civil unrest, ethnic conflicts, economic crises and weak or non-existent banking systems, as well as to the conditions of economic sanctions and blockades. The informal system of the "hawala" exists for a very long time and has recently appeared in the conflictridden countries like Afghanistan, Iraq, Kosovo and Somalia" (Lee et al., 2005).

The foreign experts state that: "Hawala has become a channel for drugs trade, arms trade, human trafficking and legalizing kickbacks," said Joginder Singh, former director of CBI. "It is also used to pay for insurgency in Kashmir, north east, to support terrorists' outfits and fundamental parties," he added. Given its informal nature, there is no precise measure of how much money is sent to India through Hawala. Interpol has placed the size of Hawala money in India at possibly $40 \%$ of the country's gross domestic product. According to the most recent figures available from the Interpol website, there is a huge $\$ 680$ billion of money in the country's Hawala system. The Audit giant KPMG International estimates that the amount can be up to $\$ 1.5$ trillion and some of that money ends up in the hands of terrorist groups (Nazakat, 2008).

In a general sense, the structure of such financial systems is similar to the classic network scheme, inherent in modern transnational criminal groups. Accordingly, counteraction against these trends should be based on appropriate methods.

For example, the UK's Serious Organized Crime Agency (SOCA) considers the "hawala", among other things, as a channel of "laundering" and international transfers of money from drug trafficking. Therefore, the "hawaladars" supporting major drug traffickers become the main object (Terraoko, 2015).

Specialists dealing with money laundering distinguish two senses of the term "hawala"-the term "white hawala" refers to legitimate transactions, the term "black hawala" refers to illegal transactions, such as illegal money laundering (Nourbakhsh, 2004).

The main specific feature of the "hawala" is that it is the least technological transactions system in the modern super technological world. Accordingly, the latest achievements of law enforcement bodies and special services are often powerless because the "hawala" is invisible to them. Hence the "good old" methods of detective work come to the forefront, such as the crime intelligence that is based on the infiltration of natural sources of information into the concerning environment and obtaining information from them "online". This method is indispensable for monitoring the processes in the sphere of the "hawala". The defeat of the Azerbaijani-Russian international criminal organization, where the finances had been based on the system of «Hawala», illustrates a positive example of a carefully prepared detective work. All the facts of remittance have been documented; the phones of employees and managers of the "hawala" have been wiretapped. After obtaining sufficient evidence, criminal proceedings were initiated; ten leaders of the "hawala" (including Elchin Dzhabrailov, Diloromi Talbak, Shanlik Shukurov) were arrested by the decision of the Moscow City Court. Subsequently, they have been charged under several articles of the Criminal Code, including Article 210 (organization of a criminal community) and Article 172 (illegal banking activities) and all of them were sentenced to long prison terms (Terraoko, 2015).

There is also a descriptive international experience in this field. In May 2006, in India, activists of the radical group "Lashkar-e-Taiba", had committed a series of 
explosions that killed hundreds of people. All these attacks had been financed through the "hawala". Indian police could disclose them only after informants have been introduced into the "hawaladars" environment. In addition, they were able to persuade the operators of the system to secretly cooperate with the investigation in exchange of a promise not to bring them to justice (Ponomarev, 2006).

Another feature of the "hawala" is that it exists wherever there are any commercial facilities-large and small stores, illegitimate markets, etc. Accordingly, identification of these features should start there, using the standard police search methods.

This is evidenced by the experience of Russian law enforcement officers who have found a cell of the "hawala" in the infamous Moscow's Cherkizovsky market. It had been working in the CIS, Europe and Middle East; up to 14 billion rouble had passed through the cell in two years. Mostly, the customers of the "hawala" were the market traders, who sent money to families, providers of goods, etc. The transfers were different-from small amounts to several million euros. If the "hawala" did not have its office in the destination city, its representatives asked for help from their colleagues involved in similar illegal business (TAXC Limited, 2011).

According to some reports, similar processes occur in Kazakhstan when flea markets, where cells of the "hawala" had emerged and expanded, become sources of terrorism financing (Terraoko, 2015).

Scientists predict that along with the final transition to the Dagestan type of terrorism there would be found new sources of financing-control over flea markets, selling drugs, racketeering, theft. Among them is formation of the "hawala" network for finances transfer (Shibutov and Abramov, 2012).

\section{Conclusion}

Taking into consideration the aforesaid, the following measures are proposed to combat this social phenomenon.

The methodology of combating these phenomena does not require a complete elimination of the "hawala" at the initial stage, since besides the social damage it also renders some useful services to the poorest segments of the population in many countries.

There should be built a thorough system of monitoring the processes taking place in this area, for registering the facts of financing terrorism, extremism and transnational organized crime. Such facts shall be addressed by state and interstate counteractions to reduce the impact of the most dangerous threats to international and regional security. There is no need to actively suppress the informal function of the "hawala" in transfer of the money earned by migrant workers from country to country, because this may lead to a sharp redistribution of migratory flows, the growth of protest moods and, as a result, the emergence of mass unrest with all ensuing consequences. Such approach coincides with the international principles. The law enforcement agencies should seek to maximize the transparency of migration flows and the accuracy of the corresponding statistics. According to the UN reports, despite the fact that the "hawala" can be used to finance terrorism, in many parts of the world, it plays a sufficient role for those who cannot afford to use the services of the official financial systems (CP, 2010).

Due to the obvious competitive advantages over the existing banking system, the physical elimination of "hawala" cannot be implemented. The only alternative, in our opinion, is to provide a convenient and inexpensive official counterpart, which will make the global banking system more economically expedient, but also evolve it (Kaukenova, 2012).

First of all, for the transition to official systems the authorities require a clear understanding and vision of the system (what methods of remittance are commonly used), the transfer corridors (which corridors operate the largest amounts of the informal remittance), service providers (who renders the services) and customers (who refers to informal service providers). Experts believe that useful information can be received from a survey of entrepreneurs, especially those involved in international and informal trade.

A careful analysis of the information obtained would provide an opportunity to discuss specific strategies and plans for the transformation of informal remittances to the official. Bringing these services in accordance with the official requirements is a potential solution, successfully used in the past by many countries. It is necessary to create legal and regulatory conditions that would allow these informal systems like the "hawala" to legalize and submit an application for a license or registration.

At the same time the official banking systems of international money transfer should become more affordable for the majority of population in the developing countries in terms of lower interest rates and the extensive infrastructure of financial institutions.

Only then, in the course of natural interests redistribution of senders and recipients of such transactions, the "hawala" and other similar systems would become less widespread, more transparent and therefore-"inconvenient" for terrorists and organized crime communities.

Of course, it is not beneficial for the owners of financial institutions, who will have to reduce their level of profitability. But, unfortunately, in the modern world, we are constantly forced to choose between the greater and lesser evil. The greater evil here is virtually unimpeded financing of terrorist, extremist and criminal groups. 
It is necessary to unite the efforts of various government agencies, both law enforcement and fiscal. The first step could be creation of the joint analytical groups of experts possessing the necessary knowledge of the functioning of informal funds transfer systems. The main task of these groups should be development of the practical recommendations for the various departments to identify the main financial channels of these systems and their monitoring for signs of terrorism, extremism and especially dangerous manifestations of transnational organized crime.

In conclusion, the above facts and opinions may indicate a possible significant impact on the shadow and legal economy and informal funds transfer systems of Kazakhstan, based on the principles of "hawala". At the same time, their serious study and evaluation of the social consequences for society and the state are not conducted, which indicates apparent underestimation of the severity of such non-traditional threats.

\section{Acknowledgment}

The authors appreciate the Science Committee of the Ministry of Education and Science of the Republic of Kazakhstan for financial support for this research article.

\section{Author's Contributions}

Both authors have made good contributions to the development and publication of this manuscript.

\section{Ethics}

This paper is original and contains unpublished material. All of the authors have read and approved the manuscript and no ethical issues involved.

\section{References}

Ballard, R., 2006. Hawala: Criminal haven or vital financial network? University of Leiden.

Benitsky, A.S., B.G. Rozovskii and O.Y. Yakimov, 2008. Responsibility for the legalization of criminally acquired funds in the criminal legislation of the Russian Federation and Ukraine.

Chene, M., 2008. Role of Hawala remittance systems in money laundering finance essay. UK Essays.

De Soto, H., 1990. The other path: The invisible revolution in the third world. J. Latin Am. Stud., 22: 403-405.

Faith, D.C., 2011. The hawala system. Global Security Studies, 2: 23-33.

Greenberg, M.R., W.F. Wechsler and L.S. Wolosky, 2002. Terrorist financing. Report of an Independent Task Force by the Council on Foreign Relations, pp: 17-18.
Katzman, K., 2011. Afghanistan: Post-Taliban governance, security and U.S. policy. Congressional Research Service.

Kaukenova, T., 2012. Keepers of cash chains. Informational and analytical portal "Terra America".

Khokhlov, I., 2007. Shadow and light of the "Hawala". Voenno-promyshlennyj kur'er.

Lee, C.S., M. Boekkerink and R. Hernandez-Coss, 2005. Approaches to a regulatory framework for formal and informal remittance systems: Experiences and lessons. Washington, DC International Monetary Fund.

Maimbo, S.M., 2003. The money exchange dealers of Kabul: A study of the Hawala system in Afghanistan. World Bank Publications.

Nazakat, S., 2008. Tracking the dirty money.

Nourbakhsh, A.A., 2004. Iran: Majlis reformists take on the money launderers. Iran Focus,

Pantucci, R., 2010. Uyghurs convicted in Turkestan Islamic movement plot in Dubai. Terrorism Monitor.

Pohoata, I. and I. Caunic, 2007. Informal value transfer system-Hawala. Theoretical Applied Econo., 4: 3-8.

Ponomarev, I., 2006. Hawala in disgrace. National Banking J. Analytics Comments.

Robinson, J., 2003. The sink: Terror, crime and dirty money in the offshore world. London, Constable.

Russian Encyclopedia "Tradition", 2012. Hawala. Russian Encyclopedia "Tradition".

Samarasinghe, S., 2006. Harry to answer for premium deal. Sunday Leader.

Shibutov, M. and V. Abramov, 2012. Terrorism in Kazakhstan in 2012. Public Lecture at the Club of the Political Solutions Institute.

Shvarev, A., 2005. The secrets of "Cherkizona": Money of traders went into "Hawala".

TAXC Limited, 2011. Money laundering in Russia. The "Hawala" on Cherkizone.

Terraoko, 2015. Hawala (Hawala)-shadow banks.

CP, 2010. Annex to the letter dated 3 December 2009 from the chairman of the security council committee established pursuant to resolution 1373 (2001) concerning counter-terrorism addressed to the president of the security council. The Conference Portal.

Todoroki, E., K. Celik and M. Holmatov, 2011. Alternative remittance systems in Kazakhstan.

UD, 2007. In Ukraine, there is a possibility of raising money for terrorists. Ukraine Daily. 